\title{
Smart Specialization and EU Eastern Innovation Cooperation: A Conceptual Approach
}

\author{
Gunnar Prause \\ Department of Business Administration, \\ Tallinn University of Technology \\ Akadeemia tee 3 , \\ Tallinn 12618, Estonia \\ E-mail: gunnar.prause@ttu.ee
}

Abstract: The concept of smart specialization as a policy approach for regional development through increased regional productivity and competitiveness in the European context is actively discussed (European Union, 2009; OECD, 2014). Meanwhile, smart specialization has found its way into EU cohesion policy as well as into the European Commission's Innovation Union flagship programme.

In Eastern Europe, economic growth came to a sudden halt during the financial crisis in 2008/2009, leading to mass unemployment, economic decline and shrinking public spending. The economic downturn in Russia after 2008 was triggered by the outflow of capital and avoided large-scale social consequences.

The paper highlights the main conceptual aspects of the smart specialization approach in the European Union and its implications on future EU Eastern Innovation cooperation with a special focus on EU's largest Eastern partner Russia.

Keywords: EU Eastern cooperation, Innovation Policy, regional development, smart growth, smart specialization 


\section{Introduction}

For today's economic growth, investments in the creation of knowledge assets, acquisitions of new skill sets or market initiatives are of equal importance to different forms of factor stocks (OECD, 2010). Although there are several ways in which they translate into economic growth, they exert major influence on both levels of income and economic wellbeing, and are likely to persist. Cumulative processes might have historical reasons, or have happened by chance, and ever since have been the subject of historical and economic discussions. Such analyses of regional differences started with the emergence of a different industry structures (Iammarinao \& McCann, 2006) or population specifics (Ciccone \& Hall, 1996; Carlino et al., 2007), but also differences in institutional settings and skill sets. Also, geographical approaches to innovation have long been discussed in management literature and go back to contributions such as Porter (1990), Jaffe et al. (1993) or Anselin et al. (1997). Of special interest are those regional differences for the so-called 'third way' of thinking. Especially the new economic geography (NEG) model (Krugman, 1991; Fujita \& Krugman, 2004) discusses agglomeration processes and economies of scales generated through specialization. While most traditional approaches based on neoliberal arguments deny transaction costs and see a removal of all barriers from common exchange as purely beneficial to all participants, new economic geography discussed regional specificities as being more differentiated. Now, the region has moved into the focus of attention to systematically study innovation activities (Cooke \& Morgan, 1998). The level has become more nuanced and now the level of knowledge flow between actors is discussed at great length. To a lesser extent, NEG is focused on policies and rather sees the succeeding of regions through more competition among actors, more innovation experts, more learning opportunities and the attraction of talent. Most contributions study very well-performing regions, neglect all other places and focus mainly on internal, endogenous factors within the region (Hadjimichalis \& Hudson, 2007).

Among the most enthusiastic recipients of this new line of thinking were policy makers. Especially at the local and regional level, policy makers felt strongly encouraged to actively engage with innovation actors to enable local and regional growth. Now, the focus is shifted to knowledge-related institutions (Cooke \& Morgan, 1998), entrepreneurship (Sternberg, 2011), or different levels of transaction costs of knowledge (McCann, 2008). Consequently, modern regional innovation policy addresses market failures and system failures caused by insufficient knowledge exchange and institutional weakness. 


\section{Smart specialization and regional innovation in the European Union}

Since 1995, the widening productivity gap between the USA and Europe became a concern to policy makers, who, in turn, searched for new policy responses. When the European Commission turned to the expert group 'Knowledge for Growth', the team suggested the 'smart specialization' approach (McCann \& Ortega-Argiles, 2013; 2014). In line with systematic perception of innovation, the concept focused increasingly on the regional context of innovation activities.

Consequently, the European Union followed these principles and stressed the importance of embeddedness and connectedness as criteria for fund allocation. Tripartite cooperation, that is university/research institution/company cooperation, peer assessment of R\&D programs, spurring creativity and entrepreneurial spirit became the new paradigm (Camagni \& Capello, 2013). Regional innovation strategies for smart specialization build on a region's capabilities, competences, competitive advantages and potential for excellence on a global perspective. They foster stakeholders' engagement and are evidencebased. Regional policy makers were advised to create the necessary conditions, such as human capital formation and development for new "knowledge needs" once the regions abandon their traditional industries and adopt new technologies (McCann \& Ortega-Argiles, 2013).

Capello and Lenzi (2012) developed a database of the regional innovation taxonomy of European regions. The database differentiates between five regional patterns which are listed here in order of their declining innovation performance, where a region with the highest innovation performance is called European science-based area, followed by applied science area, smart technology application area, smart and creative diversification area, and, finally, a region with the lowest performance called imitative innovation area (Fig. 1).

The map shows a large variety of innovation patterns and the concentration of science-based areas in Central Europe and the increasingly important knowledge centers such as Paris, London or Helsinki. The areas with the lowest knowledge and innovation intensity are located in the new EU Member States in Central and Eastern Europe and Southern Italy. Differences in the European innovation map demonstrate the abundance of the one-size-fits-all innovation policies. So, smart specialization has to be integrated into regional policy, which promotes regional technological diversification amongst the regionally dominant industries. 
Figure 1. Territorial patterns of innovation in Europe.

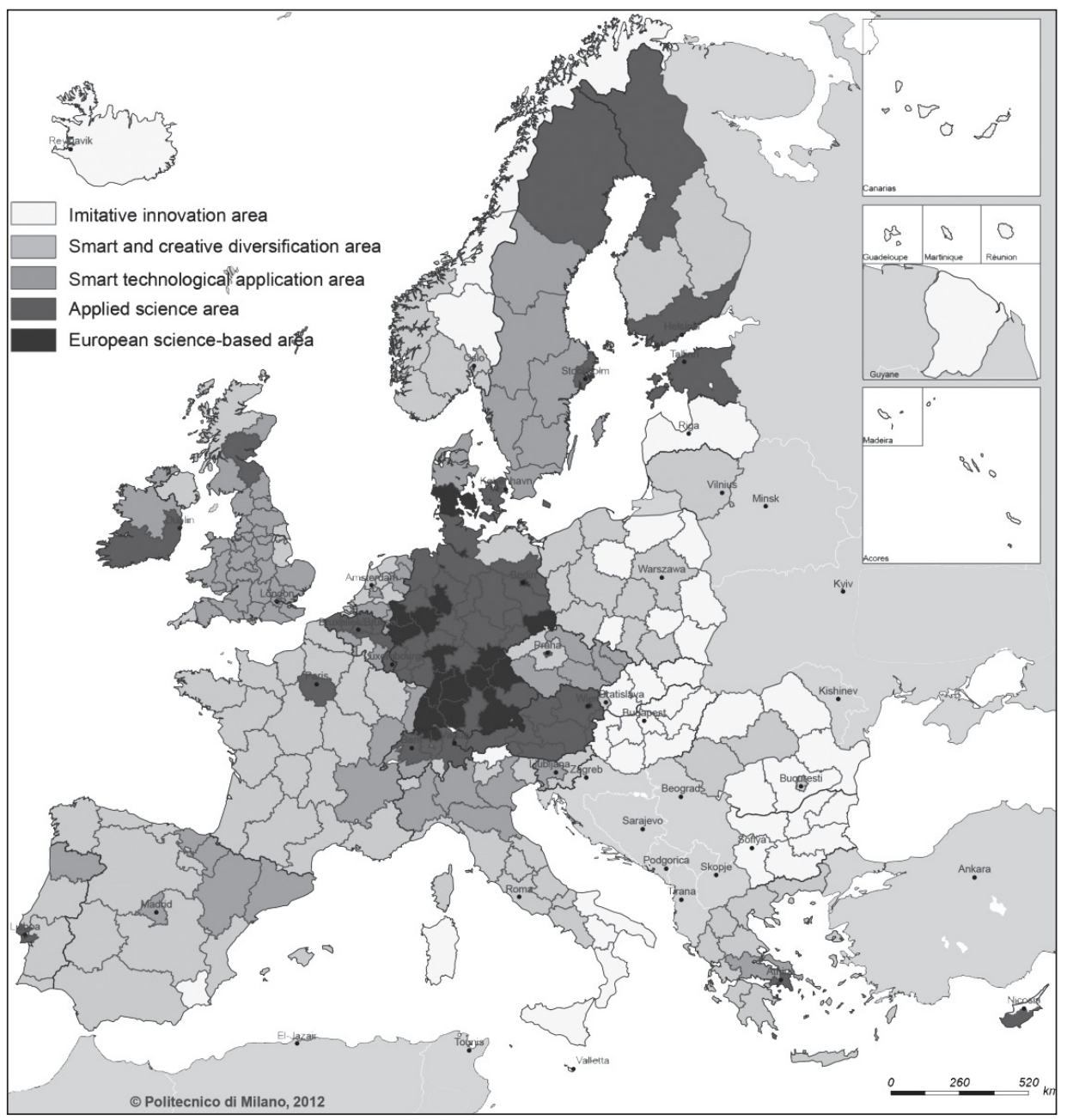

Source: Capella \& Lenzi, 2012

Smart specialization is of special relevance for intermediate regions consisting of urban and rural areas as well as for smaller regions with urban centers (OECD, 2011). For these intermediate regions, a smart policy mix consisting of $\mathrm{R} \& \mathrm{D}$, training and networking programs, together with a prioritization and concentration of resources around regional key topics, seems to be a promising approach. The related policy-development process involves the gathering of evidence and data, building of public-private partnerships and the monitoring of all political actions and interventions. 
A vital step for policy makers to position themselves is to choose priorities. For the European Union, the focus rests on smart specialization to foster strategic technological diversification around a region's core activities, encouraging processes of entrepreneurial discovery.

One of the key concepts of the smart specialization approach is the self-discovery or entrepreneurial discovery process so that smart specialization has to be flanked by supporting entrepreneurial self-discovery, as well as by fostering innovation activities in the different regions (OECD, 2014). From different studies it is well known that entrepreneurship and innovation enjoy six important economic patterns, revealing that core regions offer a greater potential for smart growth.

The first observation is that the concentration of entrepreneurship and innovation tend to be higher in cities and more densely populated regions (Acs, 2002; Carlino et al., 2007). Furthermore, van Oort (2004) found that the concentration of entrepreneurship and innovation tends to be higher in more sectorally diversified regions. Duranton and Puga (2001) pointed out that the concentration of entrepreneurship and innovation tends to be higher in regions that are less dominated by a small number of large firms, and McCann and Acs (2011) were able to show that the concentration of entrepreneurship and innovation tends to be higher in regions with a large number of multinational companies. Finally, McCann and Ortega-Argiles (2013) revealed that the concentration of entrepreneurship and innovation tends to be higher in regions with a large market potential and in many parts of the world, including the OECD countries where the use of ICT appears to have exacerbated differences between core and non-core regions.

Taking into account these facts about entrepreneurship, it is clear that a onesize-fits-all regional innovation development concept will not lead to a more balanced regional innovation performance in Europe. Furthermore, it can be stated that regional success heavily depends on entrepreneurial performance and the related capacity to build public-private partnerships and cooperation.

According to the Global Entrepreneurship Monitor (GEM, 2011; 2014), there are major differences between the European Union and Russia already in the field of entrepreneurship. In the GEM reports $(2011,2014)$, Russia belongs among the efficiency-driven economies and, compared to the EU Member States in Central Europe, shows significantly lower rates for all kinds of entrepreneurial activities. A special weakness in Russia's entrepreneurial activities appears in the high-tech sector where Russia's figures are significantly below even EU underperformer states like Romania (GEM, 2011). As possible reasons for 
the Russian entrepreneurship development, experts mention the framework conditions which reveal weaknesses in bureaucracy, R\&D transfer, financial support, and governmental programs and policies.

\section{The role of universities in EU regional innovation policy}

With the growing importance of knowledge economy since the early 1990s, the focus on the region became a key factor for prosperity in the $21^{\text {st }}$ century as there are differences in the development of different regions (Porter, 2000). Other scholars emphasize, next to geographical settings and spatial aspects, also the external environment which influences heavily regional development and networks (Florida, 2002; Bluhm et al., 2008). In the concepts of regional knowledge networks, universities occupy a special role due to their expertise in the areas of education, innovation, and technology transfer. This innovation aspect is also central in competence networks, involving universities as regional innovation engines for new business and regional network creation. This is because knowledge and skills have become the prerequisites of SMEs' and regions' competitiveness, in which universities are expected more than ever to actively engage in the development; this is especially the case in Central and Eastern European regions (Goddard, 2000; Meier zu Köcker, 2008).

A regionally engaged university can thus become a key asset for regional development, recognized as a "third role" for universities. It plays an important role also in the smart specialization concept as pointed out by David et al. (2009) since in many European regions there still exists a weak correlation between the regions $R \& D$ capabilities, its training specialization and its industrial structure. Research results show that the technology and innovation factor of a region, as well as the human capacities with highly educated work force, especially in correlation with entrepreneurial and technology transfer activities, have a high impact on the economic situation of regions (Kröhnert et al., 2007, p. 6; Etzkowitz, 2003; Clark, 2001).

In the context of the smart specialization approach, a smart policy mix consisting of $R \& D$, training and networking programs, as Barca (2009) has pointed out, a successful regional innovation policy in the framework of a European reformed cohesion policy should include the upgrading of local supply chains, the redesign of regional learning and local labor-training systems, the promotion of university business linkages, and the reform of local institutions. This represents a special challenge in Eastern and Central Europe, where a number of regions 
are suffering under their weakness in soft factors and innovations and which are linked to brain drain and dramatic demographic changes, and the success of the universities' third role is strongly linked to the development of regional soft factors (Prause \& Hunke, 2012; Prause \& Winkler, 2011; Hirsikoski et al., 2009).

Until now, the impact of universities as leading regional institutions for soft factor development and their role in regional network and cluster development has been neglected in research even though there is a larger set of study results especially from Eastern Germany and Central and Eastern EU Member States (Prause, 2014). Bluhm and others (2008) were able to prove that Eastern-German regions suffer from a lack of high-skilled business leaders due to low regional attractiveness. An analysis of business locations in various regions in Germany showed that factors such as life quality and location image are regional soft factors which are having an important impact on regional development even if their weight is different for different branches (Hansmann \& Höck, 2001; Brandt, 2010).

Other results of the think-tank of the German Employment Agency from 2007 revealed that cultural diversity has a significant impact on the regional innovation power, expressed in patents per capita (Niebuhr, 2006). Bussmann and Werle (2004) from the University of Halle-Wittenberg in Eastern Germany investigated the negative economic influence of crime and xenophobia on Eastern Germany and estimated that the economic damage amounted to a couple of million euros. So tolerance, security and openness represent important factors for regional prosperity in knowledge economy.

Thus it can be concluded that the impact of universities on regional development, especially for innovation and in knowledge economy, goes far beyond the hard factors. Universities are the leading regional institutions for soft factor development, including innovation, diversity management, internationalization and intercultural skills, which are especially needed in the eastern and central part of Eastern Europe, where a lot of regions suffer under weak soft factors, brain drain and dramatic demographic change. These two key groups share common cultural attitudes and they are highly important for a sustainable business development and innovation of regions. 


\section{Russia's regional innovation policy}

Innovation moved up the priority list of Russian top-level policy makers. Russia's Strategy 2020 attempts to enable the catch-up process with technologically leading nations. However, due to its immense size, the world's largest country struggles with enormous socio-economic differences on a regional level. Consequently, scientific and technological potential is unequally distributed. In addition, different regions are associated with diverse regional business environments, different competition levels, access to technology and innovation and different institutional quality. Nonetheless, also relatively newly developed regions in the East have successfully developed innovation systems in its regions (Tomsk).

Radosevic (2002) has studied regional innovation systems in Central and Eastern Europe and assessed the impact of post-socialist transformation on the regional innovative capacity. Of special interest was the move from former centralized governments with budget dominance to regionally enabled authorities. The necessary economic restructuring which came with memberships in the European Union, caused further disturbances in the local economy. Here, economic growth happened primarily in regions with access to capital and diversified economies.

An analysis of the Center for Strategic Research "North-West" distinguishes between metropolises (Moscow and St. Petersburg), innovation-ready regions, regions with unrealized intellectual potential and minimum-level innovation regions. Volkova and Romanyk (2011) distinguished between innovative regions of the European part of Russia, innovative regions in Siberia, mining regions, and regions lagging behind. Two further clusters include regions falling far behind. Despite recent contributions (Archibugi et al., 2013a, b), there is still strong demand for valuable insights into innovation and crisis response from both policy makers and academics alike.

There is not much information available on international R\&D cooperation of Russian state-owned enterprises (SOEs). During the recent years, this data has slightly improved owing to the innovation development programs of Russian SOEs, which is one of the current policy tools of the Russian government aimed at stimulating the innovation activities of major corporations. The initiative was launched in August 2010. The Government Commission on High Technologies and Innovations compiled a list of 47 largest SOEs, whose overall share in the Russian industrial turnover, according to the Russian Ministry of Economic Development, was more than 20 per cent. These enterprises were obliged to develop and implement innovation strategies. In addition, the Working Group 
of Public-Private Partnership Development in Innovation Sphere was formed, including representatives from the government, ministries, corporations, universities, and the Russian Academy of Sciences. This group was in charge of making tactical decisions regarding the innovation strategies of SOEs, technology platforms, development institutions, and public procurement for innovation. The SOEs from the approved list had to annually report to the group on the progress of implementation of their innovation strategies. The innovation strategies were developed in accordance with the official recommendations of the government. Most of them included the following strategic directions: new product development, modernization of equipment, commercialization of technologies, cooperation with universities, R\&D institutions and SMEs, participation in Russian technology platforms, and international collaboration. To shed light on specific experience of international STI cooperation in the business sector, innovation strategies of the largest Russian SOEs were examined. It appeared that each company had included international science, technology and innovation (STI) activities in its mid-term implementation plan. Though the geographic scope of Russian SOEs' linkages is relatively wide, the most frequently mentioned countries are the USA, Germany, France, the CIS countries, China, and South Korea. Several innovation projects with Italy, Japan, Canada, the UK, and Northern and Eastern European countries have also been planned. However, apart from this scarce data there is not much examples of SOEs being largely involved in international collaborative R\&D (except for Russian Railways, Aeroflot, or Gazprom).

Almost 4,000 research and development organizations are active in the Russian Federation. A large part of them, more than 40 per cent, are functionally connected with industries in the business enterprise sector. These organizations employ half of all the employees in the R\&D sector and consume 64.2 per cent of the national expenditure on R\&D.

In the 1990s, Russia changed the organization of its research. Although changes were made, many of them were rather superficial. Most industry-related research is still concentrated in a few large state-run research centers, which were founded in the hayday of the Soviet Union. Many of these organizations have found it increasingly difficult to interact with industry partners, which now face a market-oriented environment. One of the major points of critique on the reforms of the Russian innovation system was that the huge Academy of Sciences, incorporating some 400-plus research organizations, were left intact and still operate in isolation from other sectors, such as education. One of its branches, the Russian Academy of Agricultural Sciences, incorporates over 200 research organizations. 
The research system in the Soviet Union saw industry-related R\&D organizations attached to ministries. These ministries were also the final decision-making units who select the research projects to be carried out. These public outputs for industry-wide discoveries quickly lost their importance after the introduction of market-oriented reforms as many of them were simply produced by organizations which over time lost touch with their client base. The first reforms took place before the demise of the Soviet Union. In the late 1980s, technology parks were established in another attempt to close the widening technology gap with the West. From 1993 onwards, a few selected industrial research institutes were lifted to the status of public science centers, mostly around priority areas, to stop the increasing brain drain and to improve research capabilities in the country. This status ensured better funding and other privileges. A large portion of them is active in research for the Russian defense sector. The year 1996 saw the introduction of Innovation and Technology Centers. To improve the commercialization of technology, in 2003 technology transfer centers were established on the basis of license agreements. These centers provide flexible solutions for business-science cooperation, including foreign companies. They were supported by business incubators and technology parks as further intermediary organizations.

\section{Smart specialization and EU Eastern Innovation policy}

When the financial crisis hit in 2008/2009, dreams of endless economic growth in Eastern Europe came to a sudden end. Besides the sizable destruction of capital through bad investments and faulty credits, millions of families suffered greatly through mass unemployment, exploding import prices through currency devaluation and shrinking public spending. The new member states in Europe's East caught up in innovation activity before the crisis, but these activities were largely interrupted. Scholars voiced concerns that these countries might well fall behind their Western-European neighbors and that the already wide technology gap could increase even further (Filippetti \& Archibugi, 2011).

A closer look at the current innovation development in the European Union shows that all the Eastern European countries, except Estonia and Slovenia who belong to the group of innovation followers, belong to the group of moderate or modest innovators, representing the two low groups of countries in terms of innovation (Innovation Union Scoreboard, 2013). 
Figure 2. EU Member States' innovation performance.

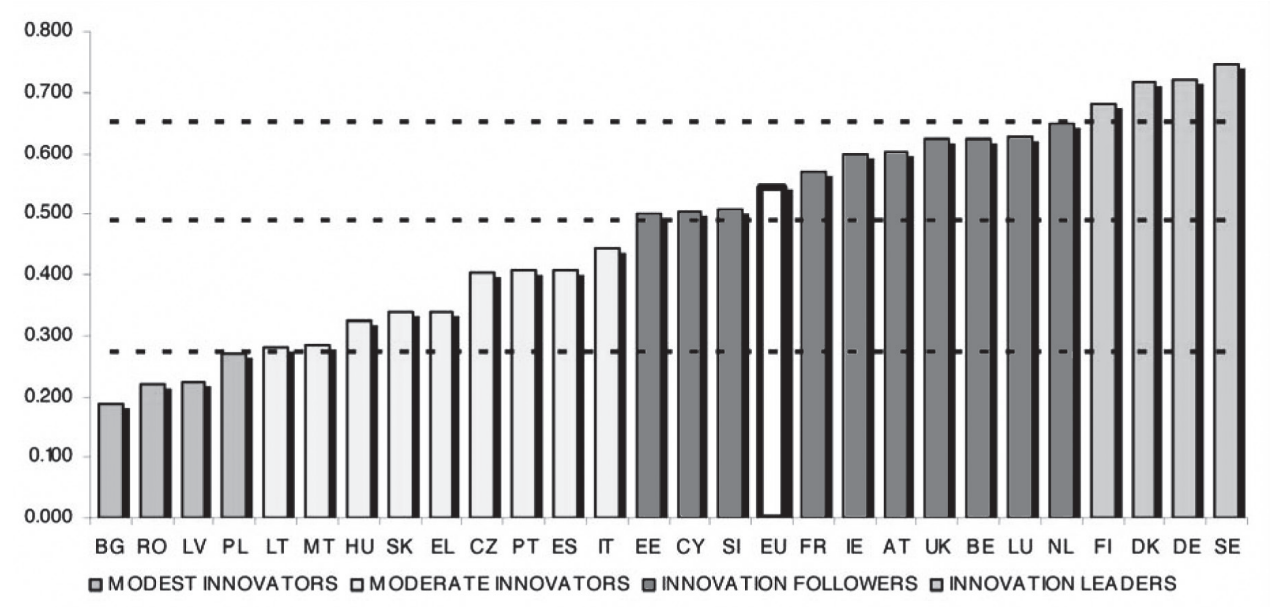

Source: Innovation Union Scoreboard, 2013, p. 5

However, considering the growth rates of innovation performance in the period 2008-2012, the picture is more promising since for a larger number of the Eastern European members the average annual growth rates were above the EU average:

Figure 3. Growth in innovation performance 2008-2012.

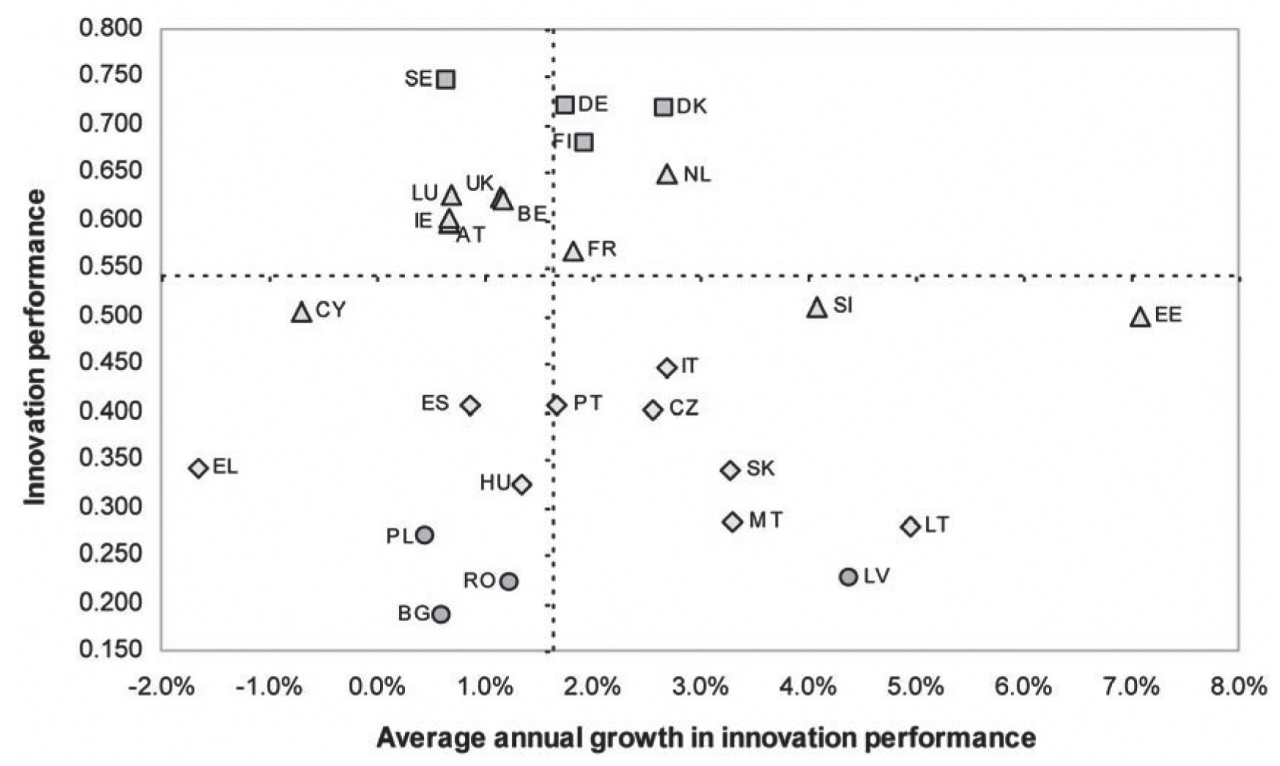

Source: Innovation Union Scoreboard, 2013, p. 11 
Even if the picture for the annual growth rates in innovation performance for the Eastern European countries between 2008 and 2012 did not look so bad, it has to be noted that for 2012, the process of convergence with the EU, which took place until 2011, has been reversed to one of divergence in 2012. The innovation gap between the EU and Russia, the most important non-EU Eastern European country, increased from -62 per cent in 2008 to -68 per cent in 2012, revealing that the Russian innovation performance is 68 per cent worse than the EU performance in 2012 (EU, 2013). This result is surprising since the Russian Federation did not show the same dramatic downturn after the financial crisis in 2008/2009, because Russia's public spending in 2009 was actually increased (Thurner, 2014).

The area under consideration here is Russia's North-Western Federal District which borders the European Union and includes St. Petersburg, the second largest city in Russia, representing, together with its surroundings, the industrial power hub of the district. Since the disintegration of the Soviet Union, it has become obvious to which extent has the innovativeness and competitiveness of Russian economy fallen behind the EU Member States, even those EU states with comparable GDP figures. Thurner (2014) has analyzed the innovation activities in Russia's North-Western Federal District and found, for the period between 2004 and 2011, that the resource-rich eastern regions have lost innovation activities whereas the western service-oriented regions of the North-Western Federal District have benefitted from innovation activities. The only exception is the Kaliningrad region which showed a decline in innovation activities. So, in fact all the EU bordering regions were able to increase their innovation activities. As Thurner (2014) points out, it is possible that these developments could have been sparked off by high-impact policy making.

\section{Concluding remarks and future research}

Smart specialization will be on the top of EU agenda between 2014 and 2020 and thus will impact significantly EU regional policy and especially EU innovation development. This influence will not only be EU internal, but will also set the frame for the future EU Eastern Innovation Partnership. The paper presents important issues of this upcoming cooperation with a special focus on EU's largest eastern partner-Russia.

Both the EU and Russia have their own Agendas 2020 and both lay special focus on entrepreneurship, public-private partnerships and building of regional 
innovation and competence networks, even though there still exist significant differences between the current situations in the EU and Russia. An important difference between the European Union and Russia lies in the international orientation of innovation and R\&D strategies. While the European approach has a high transnational aspect, the Russian innovation cooperation is still on a very low level. Here the European experience in transnational innovation projects could spur the reorientation and restructuring of the Russian innovation system.

By zooming into the conditions framing innovation in both parts of the world, there are common issues on either side of the EU borders and the main topics are related to finance, $R \& D$ transfer and entrepreneurship, so with an integrated EU Eastern Innovation approach, the cross-boundary cooperation could lead to a win-win situation for the EU and its Eastern partners. Russia is a highly interesting area especially for EU innovation activities and innovative companies, due to its well-educated R\&D personnel, the still-existing high-tech expertise in different areas and its huge and dynamic market.

Gunnar Prause is professor at Tallinn School of Economics and Business Administration in Estonia and Wismar Business School in Germany. He is co-head of the Centre for Business Research and Development at the Department of Business Administration, Tallinn University of Technology, and board member of the Institute of Cooperative Studies at Humboldt University Berlin and of the Baltic-China Science Park Network.

He has studied mathematics, informatics and business administration, has held lectures and published more than 100 scientific publications about regional development, entrepreneurship and SME management, innovation and supply chain management in international refereed journals and at international conferences. Prof. Prause enjoys a long experience in national and European projects.

Prause has worked as vice dean for research and international relations at Wismar Business School and as vice rector for research at Wismar University. He has taught and lectured at seminars, workshops and management training programmes in numerous countries in Europe, Russia, Latin America and Asia. 


\section{References}

Acs, Z. (2002), Innovation and the Growth of Cities, Cheltenham: Edward Elgar.

Anselin, L.; Varga, A. \& Acs, Z. (1997), 'Local geographic spillovers between university research and high technology innovations,' Journal of Urban Economics, vol. 42, no. 3, pp. 422-448.

Archibugi, D.; Filippetti, A. \& Frenz, M. (2013a), 'Economic crisis and innovation: Is destruction prevailing over accumulation?' Research Policy, vol. 42, no. 2, pp. 303-314.

(2013b), 'The impact of the economic crisis on innovation: Evidence from Europe,' Technological Forecasting and Social Change, vol. 80, no. 7, pp. 1247-1260.

Barca, F. (2009), An Agenda for a Reformed Cohesion Policy: A place-based approach to meeting European Union challenges and expectations. Independent report prepared at the request of Danuta Hübner, Commissioner for Regional Policy. Brussels: European Commission.

Belyakov, V.; Izosimova, A.; Koski, A.; Prause, G. \& Rudzite, M. (2010), 'Promoting Dynamic Interaction of Universities and Regional Stakeholders,' in J. W. Kramer, G. Prause \& J. Sepp (eds.) Baltic Business and Socio-Economic Development 2007, Third International Conference Tallinn, Estonia, June 17-19, 2007, Berlin: Berliner Wissenschafts-Verlag, pp. 401-444.

Bluhm, K.; Demmler, P.; Martens, B. \& Trappmann, V. (2008), Fach- und Führungskräfte in mittelständischen Unternehmen: Bedarf, Rekrutierung und Bindung. Institut für Soziologie, Working Papers: Economic Sociology Jena, vol. 6 .

Bussmann, K. \& Werle, M. (2004), 'Kriminalität - Standortfaktor für betriebliche Entscheidungen?’ Neue Kriminalpolitik, no. 3, pp. 90-95.

Brandt, A. (2010), 'Branchenspezifische Standortfaktoren,' RegioVision, vol. 3.

Camagni, R. \& Capello, R. (2013), 'Regional Innovation Patterns and the EU Regional Policy Reform,' Growth and Change, vol. 44, no. 2, pp. 355-389.

Capello, R. \& Lenzi C. (2012), 'Territorial patterns of innovation: A taxonomy of innovative regions in Europe,' The Annals of Regional Science, vol. 51, no. 1, pp. 119-154. http://dx.doi.org/10.1007/s00168-012-0539-8

Carlino, G.; Chatterjee, S. \& Hunt, R. M. (2007), 'Urban density and the rate of invention,' Journal of Urban Economics, vol. 61, no. 3, pp. 389-419.

Ciccone, A. \& Hall, R. (1996), 'Productivity and the Density of Economic Activity,' American Economic Review, vol. 86, no. 1, pp. 54-70.

Chinitz, B. (1961), 'Contrasts in the agglomeration: New York and Pittsburgh,' American Economic Review, Papers and Proceedings, vol. 51, no. 2, pp. 279-289.

Clark, B. R. (2001), 'The Entrepreneurial University: New Foundations for Collegiality, 
Autonomy, and Achievement,' Higher Education Management, vol. 13, no. 2, pp. 9-24.

Cooke, P. \& Morgan, K. (1998), The Associational Economy: Firms, Regions, and Innovation, Oxford: Oxford University Press.

David, P.; Foray, D. \& Hall, B. (2009), Measuring Smart Specialisation: The Concept and the Need for Indicators. Knowledge for Growth Expert Group. Retrieved from http://cemi.epfl.ch/files/content/sites/cemi/files/users/178044/public/ Measuring\%20smart\%20specialisation.doc [accessed Apr 2014]

Duranton, G. \& Puga, D. (2001), 'Nursery Cities: Urban Diversity, Process Innovation, and the Life Cycle of Products,' American Economic Review, vol. 91, no. 5, pp. 1454-1477.

EC (2003), The Role of the Universities in the Europe of Knowledge, Communication from the Commission Brussels, COM(2003)58 final, 05.02.2003.

(2010), Regional Policy Contributing to Smart Growth in Europe, Brussels: European Commission.

Etzkowitz, H. (2003), 'Innovation in Innovation: The Triple Helix of UniversityIndustry Government Relations,' Social Science Information, vol. 42, no. 3, pp. 293-337. http://dx.doi.org/10.1177/05390184030423002

EU (2009), Guide to Research and Innovation Strategies for Smart Specialisations (RIS 3), Research policy, Luxembourg: European Union.

Filippetti, A. \& Archibugi, D. (2011), 'Innovation in times of crisis: National Systems of Innovation, structure, and demand,' Research Policy, vol. 40, no. 2, pp. 179-192.

Florida, R. (2002), The Rise of the Creative Class: And How It's Transforming Work, Leisure, Community \& Everyday Life, Cambridge: Cambridge University Press.

Fujita, M. \& Krugman, P. (2004), 'The new economy geography: Past, present and the future,' Papers in Regional Science, vol. 83, no. 1, pp. 139-164.

GEM (2011), 'Russia,' Global Entrepreneurship Monitor 2011, GEM 2011 Global Report, London: Global Entrepreneurship Research Association.

(2014), 'GEM Global Report,' Global Entrepreneurship Monitor 2013, London: Global Entrepreneurship Research Association.

Goddard, J. (2000), The Response of HEIs to Regional Needs, Paris: OECD.

Hadjimichalis, C. \& Hudson, R. (2007), 'Rethinking Local and Regional Development: implications for radical political practice in Europe,' European Urban and Regional Studies, vol. 14, no. 2, pp. 99-113.

Hansmann, K. \& Höck, M. (2001), Standort Norddeutschland, Hamburg: Universität Hamburg.

Hirsikoski, A.; Koski, A. \& Prause, G. (2009), "Promoting Universities' 3rd TaskRecommendations for University-Business Cooperation," in G. Prause \& T. Muravska (eds.) Baltic Business and Socio-Economic Development 2008, Berlin: Berliner Wissenschafts-Verlag, pp. 351-367. 
Iammarino, S. \& McCann, P. (2006), 'The structure and evolution of industrial clusters: transactions, technology and knowledge spillovers,' Research Policy, vol. 35, no. 7, pp. 1018-1036.

Innovation Union Scoreboard (2013), Innovation Union Scoreboard, Brussels: European Union.

Jaffe, A.; Trajtenberg, M. \& Henderson, R. (1993), 'Geographic Localization of Knowledge Spillovers as Evidenced by Patent Citations,' The Quarterly Journal of Economics, vol. 108, no. 3, pp. 577-598.

Kröhnert, S.; Morgenstern, A. \& Klingholz, R. (2007), Talente, Technology und Toleranz - wo Deutschland Zukunft hat, Berlin: Berlin-Institut für Bevölkerung und Entwicklung.

Krugman, P. (1991), 'Increasing returns and economic geography,' Journal of Political Economy, vol. 99, no. 3, pp. 483-499.

Martens, B.; Michailow, M. \& Schmidt, R., eds. (2003), Managementkulturen im Umbruch, Sonderforschungsbereich 580, vol. 10.

McCann, P. (2008), 'Globalisation and economic geography: the world is curved, not flat,' Cambridge Journal of Regions, Economy and Society, vol. 1, no. 3, pp. 351-370.

McCann, P. \& Acs, Z. (2011), 'Globalisation: countries, cities and multinationals,' Regional Studies, vol. 45, no. 1, pp. 17-32.

McCann, P. \& Ortega-Argiles, R. (2013), 'Modern regional innovation policy,' Cambridge Journal of Regions, Economy and Society, vol. 6, no. 2, pp. 187-216. http://dx.doi.org/10.1093/cjres/rst007

— (2014, in press), 'Smart Specialisation, Regional Growth and Applications to European Union Cohesion Policy,' Regional Studies. http://dx.doi.org/10.1080/0 0343404.2013.799769

Meier zu Köcker, G. (2008), Clusters in Germany: An Empirical-based Insight View on Emergence, Financing, Management and Competitiveness of the Most Innovative Clusters in Germany, Berlin: Institute for Innovation and Technology \& Initiative Competence Networks Germany.

Niebuhr, A. (2006), 'Migration and Innovation. Does Cultural Diversity Matter for Regional R\&D Activity?' HWWI Research Paper, vol. 3, no. 1, Hamburg: Hamburg Institute for International Economics.

OECD (2010), Typology of regional innovation systems, Paris: OECD.

(2011), Territorial Outlook, Paris: OECD.

(2014), Innovation-driven Growth in Regions: The Role of Smart Specialisation, Paris: OECD.

van Oort, F. (2004), Urban Growth and Innovation: Spatially Bounded Externalities in the Netherlands, Aldershot: Ashgate.

Porter, M. E. (1990), The Competitive Advantage of Nations, New York: The Free Press. 
- (2000), 'Location, Competition and Economic Development: Local Networks in a Global Economy,' Economic Development Quarterly, vol. 14, no. 1, pp. 15-34.

Prause, G. (2014, in press), 'University - Business Interaction in Times of Demographic Change,' Innovations.

Prause, G. \& Hunke, K. (2012), 'University - Business Interaction in the Context of Demographic Change,' in T. Muravska \& G. Prause (eds.) European Integration and Baltic Sea Region Studies: University-Business Partnership through the Triple Helix Approach, Berlin: Berliner Wissenschafts-Verlag, pp. 188-199.

Prause, G. \& Winkler, K. (2011), “Universities' third task: On the way towards the entrepreneurial university - A German Case Study,' in G. Prause, U. Venesaar (eds.) University-Business Cooperation: Tallinn 2011, Berlin: Berliner WissenschaftsVerlag, pp. 52-63.

Radosevic, S. (2002), 'Regional innovation systems in Central and Eastern Europe: determinants, organizers and alignments,' The Journal of Technology Transfer, vol. 27 , no. 1 , pp. 87-96.

Sternberg, R. (2011), 'Interregional Disparities, Entrepreneurship, and EU Regional Policy,' in M. Minniti (ed.) The Dynamics of Entrepreneurship. Evidence from the Global Entrepreneurship Monitor Data, Oxford \& New York: Oxford University Press, pp. 153-80.

Thurner, T. (2014, in press), “Innovation in turbulent times - Russia's North-Western Federal District and the financial crisis," Regional Studies. 